\title{
Rancang Bangun Sistem Penjejak Matahari 1 Sumbu (Axis) Menggunakan Metode Fuzzy Logic Untuk Optimalisasi Daya
}

\author{
${ }^{a}$ Rizki Fajar Amirudin, ${ }^{b}$ Istyo Winarno \\ ${ }^{a, b}$ Fakultas Teknik dan Ilmu Kelautan, Universitas Hang Tuah Surabaya \\ Jalan Arif Rahman Hakim No. 150, Keputih-Sukolilo, Surabaya 60111 \\ ${ }^{a, b}$ Email : exrizki5471@gmail.com, istiyo.winarno@gmail.com
}

\begin{abstract}
Abstrak
Masalah energi merupakan topik penelitian yang menarik sepanjang peradaban umat manusia. Upaya mencari sumber energi alternatif sebagai pengganti bahan bakar fosil masih tetap ramai dibicarakan. Energi matahari merupakan energi yang berjumlah sangatlah besar dan masih sangat sedikit digunakan. Pada dasarnya prinsip dari memanfaatkan energi matahari adalah mengkonversi cahaya matahari yang diserap oleh panel surya diubah menjadi listrik. Panel surya dapat optimal ketika berhadapan langsung dengan pancaran sinar matahari, dalam artian posisi panel surya harus tegak lurus dengan cahaya yang datang. Penelitian ini menggunakan sistem kendali fuzzy logic untuk mengatur posisi panel surya agar selalu tegak lurus menghadap matahari dengan manggunakan sensor cahaya (LDR) untuk mendeteksi posisi matahari. Pada kondisi cuaca yang hampir sama panel surya dengan sistem penjejak menghasilkan daya rata-rata 42,04 Watt sedangkan panel tanpa sistem penjejak meghasilkan daya rata-rata 38,52 Watt. Panel surya dengan sistem penjejak mempunyai keluaran daya rata-rata 3.52 Watt lebih besar daripada panel surya tanpa sistem penjejak.
\end{abstract}

Kata kunci : Energi Alternatif, Fuzzy Logic, LDR, Solar Cell.

\begin{abstract}
:
Energy issues are an interesting research topic throughout human civilization. Efforts to find alternative energy sources to replace fossil fuels as they are often discussed, Solar energy is a very large amount of energy and is still very little used. Basically, the principle of using solar energy is to convert sunlight absorbed by the solar panels is converted into electricity. Solar panels can be optimal when dealing directly with the sun, in the sense that the position of the solar panel must be perpendicular to the light coming. This research uses fuzzy logic control to adjust the position of the solar panels to always be perpendicular to the sun with light sensor (LDR) to detect the position of the sun. Then the results obtained from the measurement of solar panel power with solar tracking system compared to solar panel power that does not use sun tracking system. In similar weather conditions, solar panels with tracking systems have an average power of 42.04 Watt, while solar panels without tracking systems have an average power of 38.52 Watt. Solar panels with tracking systems have an average output power of 3.52 Watt larger than solar panels without a tracking system.
\end{abstract}

Keywords : Alternative Energy, Fuzzy Logic, LDR, Solar Cell.

\section{PENDAHULUAN}

Pada saat ini upaya mencari sumber energi alternatif sebagai pengganti bahan bakar fosil masih tetap ramai dibicarakan. Terdapat beberapa sumber energi alam yang tersedia sebagai energi alternatif yang bersih, tidak berpolusi, aman dan dengan persediaan yang tidak terbatas [1]. Salah satu energi alternatif yang hampir mencakup kriteria aman bagi lingkungan adalah energi matahari. Energi matahari merupakan energi yang berjumlah sangat besar dan masih sangat sedikit digunakan. Jumlah rata-rata panas matahari 
yang dapat terpancarkan ke bumi sekitar $1 \mathrm{KW} / \mathrm{m} 2$ atau setara dengan 1000 kali konsumsi energi di seluruh dunia saat ini [1]. Atau dengan kata lain, dengan menutup 0,1\% saja permukaan bumi dengan panel surya yang memiliki efisiensi 10 persen sudah mampu untuk menutupi kebutuhan energi di seluruh dunia saat ini [1].

Pada dasarnya prinsip dari memanfaatkan energi matahari adalah mengkonversi cahaya matahari yang diserap oleh panel surya diubah menjadi listrik. Permasalahaanya saat ini adalah bagaimana menggunakan panel surya untuk mendapatkan keluaran listrik yang optimal. Panel surya dapat optimal ketika berhadapan langsung dengan pancaran sinar matahari, dalam artian posisi panel surya harus tegak lurus dengan cahaya yang datang (Lorenzo, 1994). Dengan memperhatikan perilaku bunga matahari yang selalu mengikuti arah matahari, panel surya perlu didesain seperti tersebut agar efektivitas kerja panel surya lebih maksimal (Lorenzo, 1994).

Tingkat penggunaan radiasi matahari dapat dimaksimalkan dengan menggunakan sistem mekanik untuk orientasi modul solar cell sesuai dengan garis edar matahari. Pada dasarnya sistem pelacakan adalah sistem mekatronika yang mengintegrasikan mekanika, elektronika, dan teknologi informasi. Mekanisme ini digerakkan oleh motor rotari atau aktuator linier, yang dikontrol untuk memastikan posisi yang optimal dari modul solar cell relatif ke posisi matahari agar selalu sejajar. Orientasi dari modul solar cell dapat meningkatkan efisiensi sistem konversi dari $20 \%$ hingga $50 \%$ [2]. Dari latar belakang tersebut maka penulis akan membuat solar tracking system yang dapat mengikuti garis edar matahari mulai terbit dari timur hingga tenggelam ke barat agar efektivitas kerja solar cell lebih maksimal dengan menggunakan logika fuzzy. Pada kondisi cuaca yang hampir sama panel surya dengan sistem penjejak menghasilkan daya rata-rata 42,04 Watt sedangkan panel tanpa sistem penjejak meghasilkan daya rata-rata 38,52 Watt. Panel surya dengan sistem penjejak mempunyai keluaran daya rata-rata 3.52 Watt lebih besar daripada panel surya tanpa sistem penjejak.

\section{METODE PENELITIAN}

Gambar 1 menunjukkan sistem keseluruhan yang dibuat :

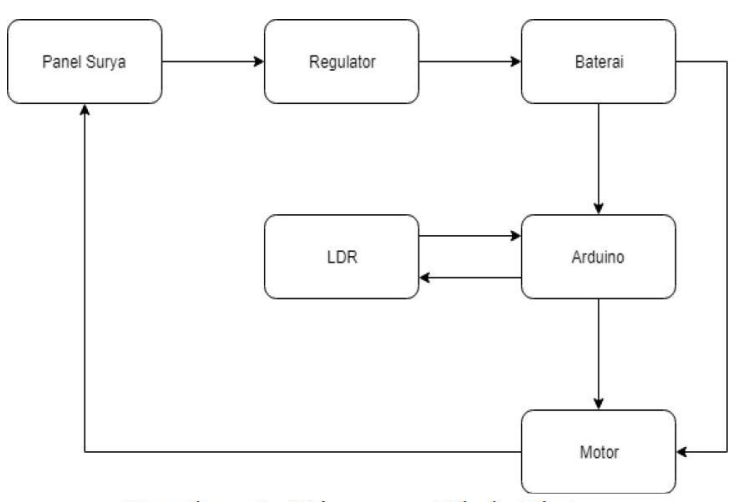

Gambar 1. Diagram Blok Sistem

Dari gambar 1 dapat dilihat mulai dari sensor LDR membaca data intesitas cahaya, sensor LDR ini terpasang pada dua sisi panel surya. Sinyal yang dikeluarkan sensor LDR menjadi masukan dari Arduino, didalam arduino terdapat logika fuzzy yang digunakan untuk membandingkan nilai dari sensor LDR yang kemudian diteruskan untuk memerintah motor apakah berputar kekanan, kekiri, dan diam. Motor tersebut yang menggerakkan panel surya agar dapat mengikuti arah cahaya matahari agar dapat mengoptimalkan daya keluaran panel surya untuk disimpan pada baterai melalui regulator.

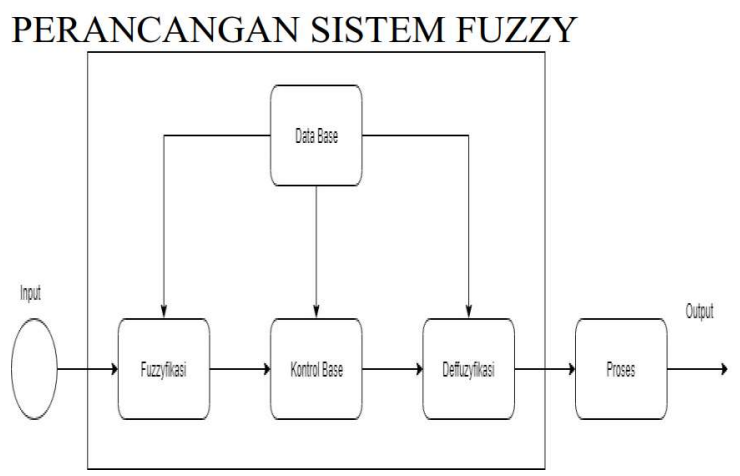

Gambar 2. Model Fuzzy Logic Controller

\section{Fuzzyfikasi}

Untuk merancang Fuzzy Logic Controller, terlebih dahulu ditentukan fungsi keanggotaan dari setiap fuzzy set. Fungsi keanggotaan akan mengkonversi nilai crisp (numerik) menjadi nilai fuzzy. Fungsi keanggotaan yang harus 
ditentukan meliputi perubahan dari keempat sensor cahaya yang akan menentukan orientasi matahari. Tujuan membentuk fungsi keanggotaan dari setiap fuzzy set adalah untuk membentuk variabel linguistik dari tiap-tiap fuzzy set. Dalam penelitian ini penulis menggunakan 3 buah variabel linguistik. Pada sensor cahaya yang akan menentukan orientasi matahari, setiap sensornya didesain menggunakan crisp input sebanyak 3 variabel. Yaitu variabel Terang ( $\mathrm{T}$ ), Kurang Terang (KT), dan Gelap (G). Sedangkan pada crisp output sebagai tindakan akan keadaan yang diterima sensor dibagi menjadi 3 variabel, yaitu clock wise (CW), center (C), dan counter clock wise (CCW).

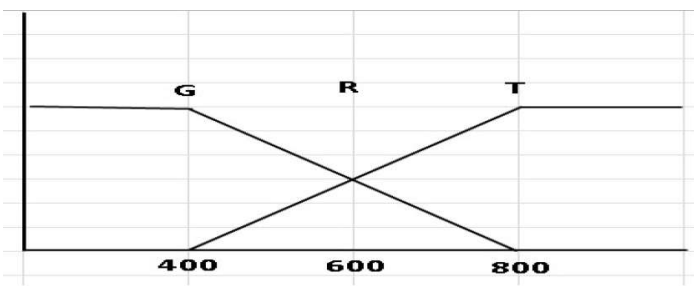

(a)

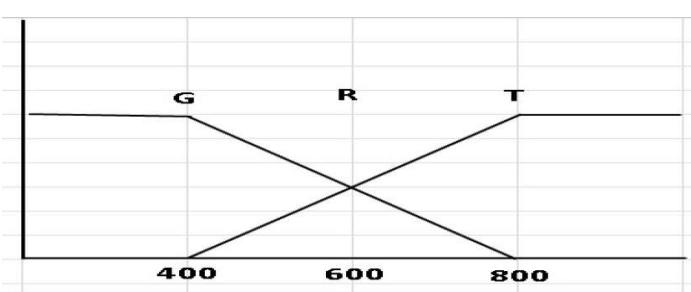

(b)

Gambar 3. (a) Fungsi Keanggotaan Input Sensor Arah Timur

(b) Fungsi KeanggotaanInput Sensor Arah Barat

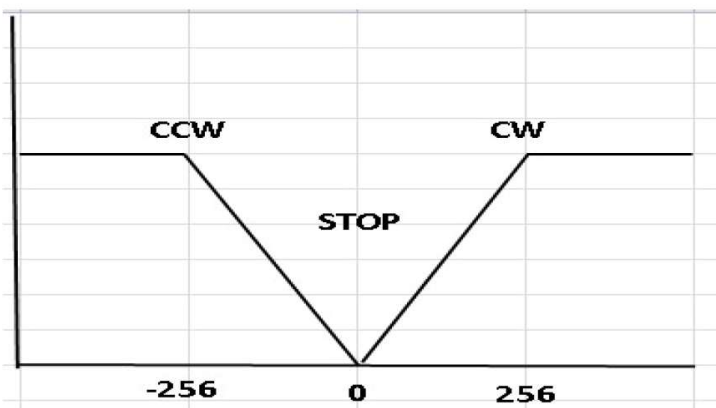

Gambar 4. Fungsi Keanggotaan Output Arah Putar Motor
Penyusunan Aturan/Rules

Aturan yang dipakai pada masukan sensor LDR1 dan LDR2 digunakan untuk mengatur motor. Dengan crisp input dari masing-masing masukan sensor dan crisp output dari masing-masing keluaran dapat dibuat aturan atau rules sebanyak 4 aturan. Aturan-aturan tersebut antara lain:

1. Jika ST Terang dan SB Terang, maka motor adalah STOP

2. Jika ST Terang dan SB Gelap, maka motor adalah CCW

3. Jika ST Gelap dan SB Terang, maka motor adalah $\mathrm{CW}$

4. Jika ST Gelap dan SB Gelap, maka motor adalah STOP

\section{HASIL DAN PEMBAHASAN}

Pengujian ini diperlukan untuk membuktikan apakah hasil keluaran panel surya bergantung terhadap posisi matahri. Data yang akan diambil pada penelitian ini adalah panel surya tanpa menggunakan sistem penjejak matahari dan panel surya yang menggunakan sistem penjejak mathari. Pengambilan data panel surya tanpa sistem penjejak matahari dan menggunakan sistem penjejak matahari dilakukan secara terpisah dengan waktu dan tempat yang berbeda, dengan kata lain tidak dilakukan pengambilan data secara real, dikarenakan adanya perbedaan dari panel surya yang digunakan. Akan tetapi data yang diambil menggunakan parameter-parameter yang sama, dan bisa dilihat pada tabel 1 dan tabel 2 .

Tabel 1. Hasil pengujian Tegangan, Arus, dan Daya Tanpa Sistem Penjejak

\begin{tabular}{|l|c|c|c|c|}
\hline \multirow{2}{*}{ Jam } & \multicolumn{4}{|c|}{ Tanpa Sistem Penjejak } \\
\cline { 2 - 5 } & V & I & Watt & Kondisi \\
\hline $\mathbf{0 9 . 0 0}$ & 18,23 & 1,91 & 34,81 & Cerah \\
\hline $\mathbf{0 9 . 3 0}$ & 18,27 & 1,92 & 35,07 & Cerah \\
\hline $\mathbf{1 0 . 0 0}$ & 19,41 & 1,89 & 36,68 & Cerah \\
\hline $\mathbf{1 0 . 3 0}$ & 19,26 & 2,11 & 40,63 & Cerah \\
\hline
\end{tabular}




\begin{tabular}{|l|c|c|c|c|}
\hline $\mathbf{1 1 . 0 0}$ & 19,63 & 2,1 & 41,22 & Cerah \\
\hline $\mathbf{1 1 . 3 0}$ & 20,04 & 2,21 & 44,28 & Cerah \\
\hline $\mathbf{1 2 . 0 0}$ & 20,08 & 2 & 40,16 & Cerah \\
\hline $\mathbf{1 2 . 3 0}$ & 20,18 & 1,99 & 40,15 & Cerah \\
\hline $\mathbf{1 3 . 0 0}$ & 19,99 & 1,99 & 39,78 & Cerah \\
\hline $\mathbf{1 3 . 3 0}$ & 20,01 & 2,01 & 40,22 & Cerah \\
\hline $\mathbf{1 4 . 0 0}$ & 18,28 & 1,99 & 36,37 & Cerah \\
\hline $\mathbf{1 4 . 3 0}$ & 18,91 & 1,89 & 35,73 & Cerah \\
\hline $\mathbf{1 5 . 0 0}$ & 18,66 & 1,91 & 35,64 & Cerah \\
\hline $\begin{array}{c}\text { RATA } \\
\text { RATA }\end{array}$ & $\mathbf{1 9 , 3 0}$ & $\mathbf{1 , 9 9}$ & $\mathbf{3 8 , 5 2}$ & \\
\hline
\end{tabular}

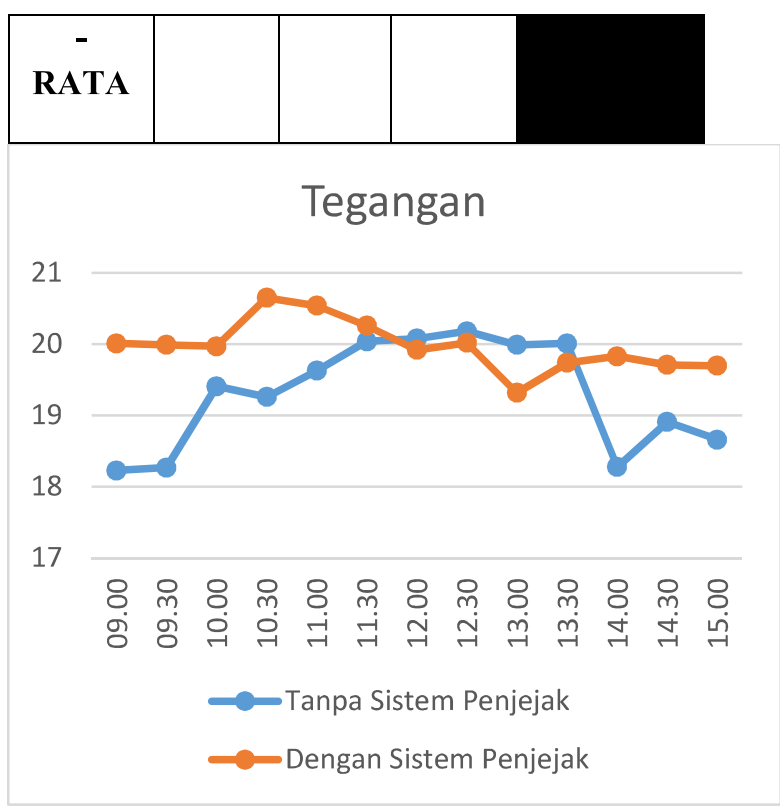

Gambar 5 Grafik Perbandingan Tegangan Terhadap Waktu

Tabel 2. Hasil pengujian Tegangan, Arus, dan Daya Dengan Sistem Penjejak

\begin{tabular}{|l|c|c|c|c|}
\hline \multirow{2}{*}{ Jam } & \multicolumn{3}{|c|}{ Dengan Sistem Penjejak } \\
\cline { 2 - 5 } & V & I & Watt & Kondisi \\
\hline $\mathbf{0 9 . 0 0}$ & 20,01 & 2,23 & 44,62 & Cerah \\
\hline $\mathbf{0 9 . 3 0}$ & 19,99 & 1,97 & 39,38 & Cerah \\
\hline $\mathbf{1 0 . 0 0}$ & 19,97 & 1,99 & 39,74 & Cerah \\
\hline $\mathbf{1 0 . 3 0}$ & 20,65 & 2,06 & 42,53 & Cerah \\
\hline $\mathbf{1 1 . 0 0}$ & 20,54 & 2,21 & 45,39 & Cerah \\
\hline $\mathbf{1 1 . 3 0}$ & 20,26 & 2,22 & 44,97 & Cerah \\
\hline $\mathbf{1 2 . 0 0}$ & 19,92 & 2,19 & 43,62 & Cerah \\
\hline $\mathbf{1 2 . 3 0}$ & 20,02 & 2,38 & 47,64 & Cerah \\
\hline $\mathbf{1 3 . 0 0}$ & 19,32 & 2,33 & 45,01 & Cerah \\
\hline $\mathbf{1 3 . 3 0}$ & 19,74 & 1,98 & 39,08 & Cerah \\
\hline $\mathbf{1 4 . 0 0}$ & 19,83 & 1,99 & 39,46 & Cerah \\
\hline $\mathbf{1 4 . 3 0}$ & 19,71 & 2,01 & 39,61 & Cerah \\
\hline $\mathbf{1 5 . 0 0}$ & 19,7 & 1,8 & 35,46 & Cerah \\
\hline $\mathbf{R A T A}$ & $\mathbf{1 9 , 9 7}$ & $\mathbf{2 , 1}$ & $\mathbf{4 2 , 0 4}$ & \\
\hline & & & & \\
\hline
\end{tabular}

\section{Arus}

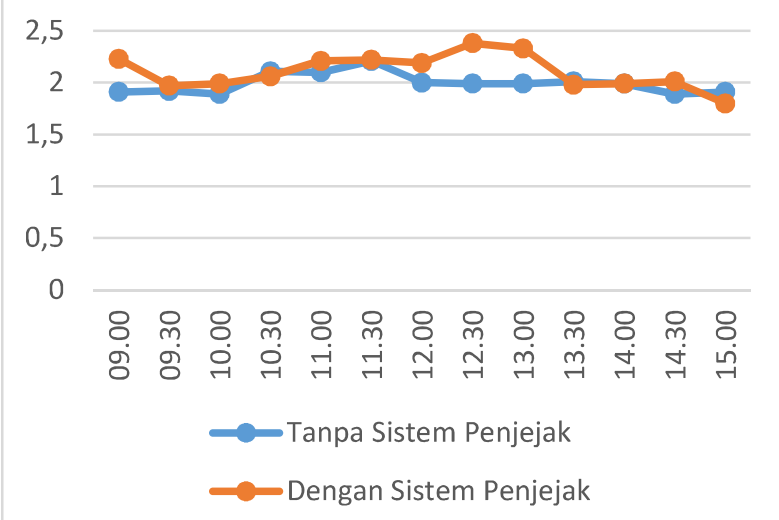

Gambar 6 Grafik Perbandingan Arus Terhadap Waktu 


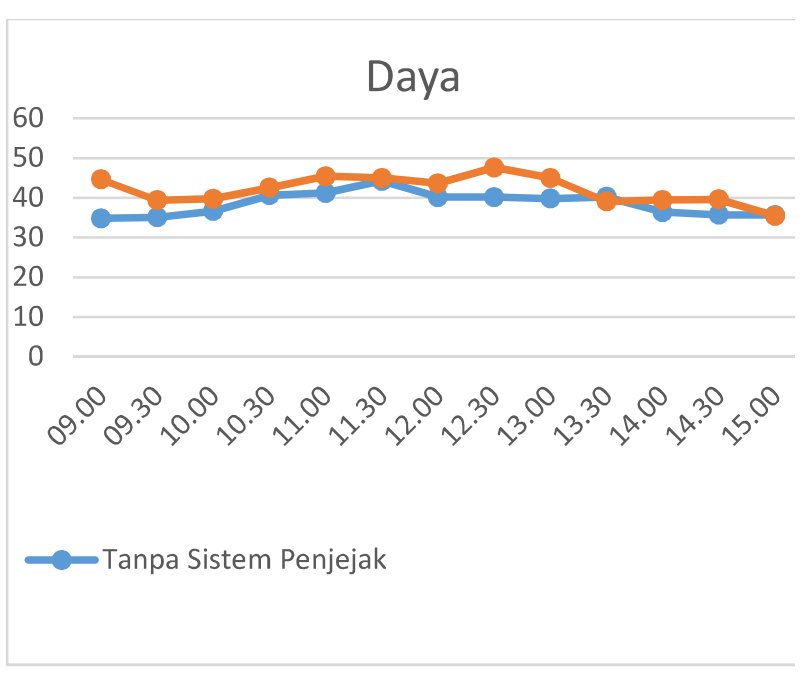

Gambar 7 Grafik Perbandingan Daya Tegangan Terhadap Waktu

Berdasarkan gambar 5 dijelaskan bahwa tegangan yang dihasilkan panel surya tanpa penjejak menghasilkan tegangan ratarata $19.30 \mathrm{~V}$ sedangkan tegangan yang dihasilkan panel surya dengan penjejak matahari menghasilkan tegangan rata-rata 19,97 V. Selanjutnya pada gambar 6 dijelaskan arus rata-rata pada panel surya tanpa penjejak sebesar 1,99 A sedangkan arus rata-rata pada panel surya dengan menggunakan penjejak matahari sebesar 2,1 A. Sedangkan daya yang dihasilkan panel surya tanpa penjejak rata-rata sebesar 38.52 Watt dan panel surya dengan penjejak matahari memiliki daya rata-rata sebesar 42.04 Watt. Dari Dengan kondisi cuaca yang sama-sama cerah mulai jam 09.00 - 15.00 terlihat dengan jelas panel surya dengan sistem penjejak lebih unggul daripada panel surya tanpa sistem penjejak.

\section{KESIMPULAN}

Dari hasil pengujian panel surya dengan menggunakan sistem penjejak matahari dan tanpa menggunakan sistem penjejak matahari maka dapat disimpulkan bahwa panel surya dengan menggunakan sistem penjejak matahari memiliki keluaran daya rata-rata yang lebih optimal yaitu sebesar 42.04 Watt dibandingkan dengan panel surya tanpa sistem penjejak matahari yaitu sebesar 38.52 Watt.

\section{DAFTAR PUSTAKA}

[1] Alfin Imadul H, Sumardi, Munawar A. 2014. Sistem Tracking Panel Surya Untuk Pengoptimalan Daya Menggunakan Metode Kendali Logika Fuzzy .Jurnal UNDIP. Universitas Diponegoro.

[2] Helaswiyono, Prayoga Anggeir . 2016. Rancang Bangun Panel Surya Statis Menggunakan Metode Maximum Power Point - Tracking (MPPT) Hill Climbing Untuk Memaksimalkan Penyerapan Daya Listrik. Skripsi. Surabaya: Universitas Hang Tuah 